\title{
Oral pemphigus as first sign of an inflammatory myofibroblastic tumour in an 18-year-old male patient
}

\author{
Rutger M Schols, ${ }^{1}$ Geerard L Beets, ${ }^{1}$ Robert G Riedl, ${ }^{2}$ Robert J Schipper ${ }^{1,3}$
}

${ }^{1}$ Department of Surgery, Maastricht University Medical Center, Maastricht, The Netherlands

2Department of Pathology, Maastricht University Medical Center, Maastricht, The Netherlands

${ }^{3}$ Department of Radiology, Maastricht University Medical Center, Maastricht, The Netherlands

\section{Correspondence to} Rutger M Schols, rutgermschols@hotmail.com
CrossMark

To cite: Schols RM, Beets GL, Riedl RG, et al. BMJ Case Rep Published online: [please include Day Month Year] doi:10.1136/ bcr-2013-201896

\section{DESCRIPTION}

An 18-year-old male patient suffered from painful oral ulcers, causing $10 \mathrm{~kg}$ body weight loss. The dermatologist diagnosed him with pemphigus, based on the clinical characteristics of the ulcers. Owing to the weight loss an abdominal mass became palpable. On CT (figure 1) a large hypervascular heterogenous solid mass was found, with central calcifications (maximum diameter $20 \mathrm{~cm}$ ). Percutaneous biopsy revealed an inflammatory myofibroblastic tumour (IMT). Pemphigus was interpreted as paraneoplastic symptom.

Owing to the hypervascularised nature of the tumour on CT, 5 days before surgery selective embolisation of the major arterial blood suppliers was performed by percutaneous angiography. En bloc resection of the tumour, left kidney and a small part of the left adrenal gland (figure 2) was performed with minimal blood loss.

The pathologist found a radically excised $19 \mathrm{~cm}$ IMT, with negative staining for anaplastic lymphoma kinase (ALK gene).
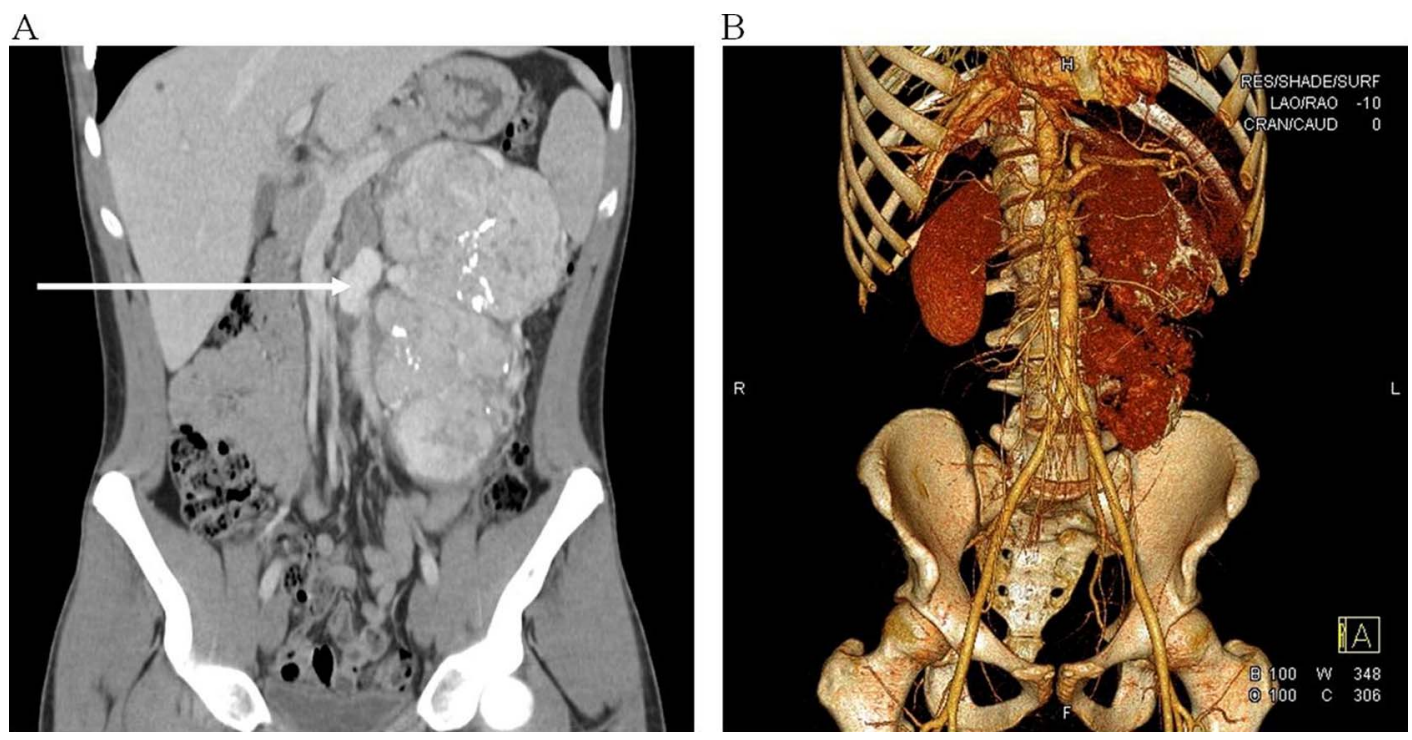

Figure 1 (A) Coronal view of the preoperative CT of the abdomen, showing a large hypervascular inhomogeneous solid tumour in the left hemiabdomen, with central calcifications (see white spots in the tumour), measuring $20 \times 9 \times 11 \mathrm{~cm}$. Multiple arterial suppliers and venous structures are detected, with a maximum diameter of $2.2 \mathrm{~cm}$ (indicated by the arrow). The tumour is possibly invading the left kidney, and is located against the spleen and psoas muscle. Furthermore, the tumour causes shift of the ascending colon and small intestine. There are no pathologically enlarged lymph nodes or signs of distant metastasis. (B) Coronal view of a vascular subtraction reconstruction of CT of the abdomen, illustrating the hypervascular state of the inflammatory myofibroblastic tumour.
Paraneoplastic pemphigus is mostly associated with haematological malignancies; it is only rarely seen with non-haematological neoplasms, such as IMT. ${ }^{1}$ IMTs are neoplasms of intermediate biological potential, composed of myofibroblastic mesenchymal spindle cells accompanied by an inflammatory infiltrate. ALK gene rearrangements are present in up to $70 \%$ of IMTs. The most common sites of origin are the abdominopelvic region, lung, mediastinum and retroperitoneum. They frequently recur locally (especially when located in the abdominopelvic region), but rarely metastasise. The latter is most often seen in ALK-negative tumours. ${ }^{2}$ Tumour excision with wide margins is indicated to minimise the chance of local recurrence. ${ }^{3}$ Time course and pattern of development of distant metastases is not well described in the literature. Owing to the high risk for recurrence, regular clinical follow-up of patients after local resection of IMT is advised. After 2 years of follow-up there were no signs of recurrence in this patient. The paraneoplastic pemphigus is in remission after radical tumour removal and adequate immunosuppressive drug therapy. ${ }^{1}$ 


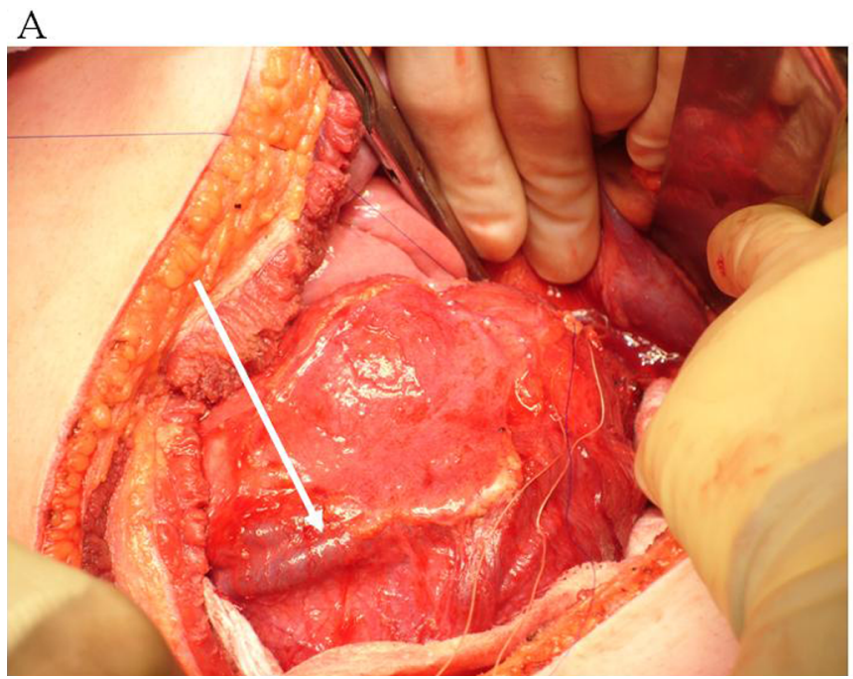

B

Figure 2 (A) In vivo image of the solid tumour with a clear exposure of a large vascular structure (indicated by the arrow). (B) Surgical specimen: en bloc resection of the tumour, left kidney and a small part of the left adrenal gland.

\section{Learning points}

- Pemphigus can present as a paraneoplastic symptom in patients with inflammatory myofibroblastic tumour (IMT).

- IMTs are neoplasms, which frequently tend to recur locally, but rarely metastasise; absence of anaplastic lymphoma kinase gene activity seems to increase the risk of distant metastasis.

- With proper preoperative workup, even in hypervascularised tumours, radical resection with minimal blood loss is feasible and indicated for local control.
Contributors All authors contributed to the writing and critical review of the manuscript.

Competing interests None.

Patient consent Obtained.

Provenance and peer review Not commissioned; externally peer reviewed.

\section{REFERENCES}

1 Lee SE, Kim SC. Paraneoplastic pemphigus. Dermatol Sin 2010;28:1-14.

2 Coffin CM, Hornick JL, Fletcher CD. Inflammatory myofibroblastic tumor: comparison of clinicopathologic, histologic, and immunohistochemical features including ALK expression in atypical and aggressive cases. Am J Surg Pathol 2007;31:509-20.

3 Sanders BM, West KW, Gingalewski C, et al. Inflammatory pseudotumor of the alimentary tract: clinical and surgical experience. J Pediatr Surg 2001;36:169-73.

Copyright 2013 BMJ Publishing Group. All rights reserved. For permission to reuse any of this content visit http://group.bmj.com/group/rights-licensing/permissions.

BMJ Case Report Fellows may re-use this article for personal use and teaching without any further permission.

Become a Fellow of BMJ Case Reports today and you can:

- Submit as many cases as you like

- Enjoy fast sympathetic peer review and rapid publication of accepted articles

- Access all the published articles

- Re-use any of the published material for personal use and teaching without further permission

For information on Institutional Fellowships contact consortiasales@bmjgroup.com

Visit casereports.bmj.com for more articles like this and to become a Fellow 